\title{
DESCOLONIZAR O ATO COLONIZADOR, RESSIGINIFICAR HISTÓRIAS:
}

\section{RESISTÊNCIAS}

\section{Rosani Ketzer Umbach ${ }^{1}$ Tânia Sarmento-Pantoja²}

Os séculos XX e XXI foram, segundo Eric Hosbabawn e Márcio Seligmann-Silva, respectivamente, a Era das Catástrofes e dos Testemunhos. Diante do olhar abismado frente às atrocidades experimentadas nesses dois séculos, resistir transformou-se em uma necessidade incontornável. Por esse motivo, não seria exagero falarmos também em uma Era das Resistências, categoria proposta por Augusto Sarmento-Pantoja, cujos formatos e performances são objetos da presente edição intitulada Literatura e Cinema de Resistência: ressignificando histórias.

O conjunto se apresenta composto por doze artigos, dos quais três estão em língua alemã e os demais em língua portuguesa. Vários desses artigos correspondem às conferências e palestras apresentadas ao longo do Seminário Nacional Literatura e Cinema de Resistência, que em sua quinta versão ocorreu, no final do ano de 2016, na Universidade Federal de Santa Maria, em ampla parceria com a Universidade Federal do Pará e a Universidade Federal de Minas Gerais. O dossiê também é formado por textos oriundos de outros laboratórios de análise das expressões da resistência.

Todos os textos realizam uma intensa escavação analítica sobre os (pre)domínios da resistência em um corpus bastante heterogêneo - que inclui filmes, minisséries, testemunhos, romances, contos, fotografias etc. Ao mesmo tempo, expõem como o confronto, o desafio e a denúncia podem ser os aspectos mais conhecidos da resistência. Entretanto, há outras condições possíveis de desencadeá-la, como a valoração, a persistência, a reintegração, o ressentimento, a reelaboração, enfim, muitas são as suas faces, porém a ressignificação parece ser uma categoria chave a habitar o conceito. De fato, contra qualquer forma de colonização - ou docilização - individual ou coletiva, o deslocamento dos signos é sempre uma demanda na imagem resistente, na escrita resistente, como é possível observar na sequência de artigos que compõe a presente edição, apresentados a seguir.

$\mathrm{O}$ artigo de abertura do dossiê, intitulado "O testemunho em três vozes: testis, superstes e arbiter", de autoria de Augusto Sarmento-Pantoja, propõe o testemunho arbiter como categoria no âmbito de uma tríade, formada não por duas pessoas do testemunho, como postula a tradição dos estudos sobre testemunho, mas por três, sendo dessa forma sistematizada pelo autor: o do testemunho

\footnotetext{
${ }^{1}$ Professora da Universidade Federal de Santa Maria - UFSM; Pesquisadora do CNPq. E-mail: rosani.umbach@ufsm.br.

2 Professora da Universidade Federal do Pará - UFPA; Pesquisadora do CNPq. E-mail: t.sarmentopantoja@gmail.com.
} 
superstes (primeiro), aquele que viveu e testemunha sua própria experiência; o testemunho arbiter (segundo), daquele que ouviu de um terceiro e arbitra o que e como narrar; e o testemunho testis (terceiro), aquele que viu e testemunhou a cena dolorosa, mas sem estar envolvido nela. Trata-se de uma contribuição fundamental para a compreensão das seleções atribuídas à memória de um evento e o alcance dos estatutos e escolhas para as possibilidades de resistência envolvidas.

"Gewaltherrschaft in Argentinien: Eine beispielhafte Analyse der Darstellung von Gewalt in Garaje Olimpo", artigo de Friederike Bischoff, compreende uma reflexão a partir de uma política de memória presente no filme Garaje Olimpo, com direção de Marco Becchis. A análise está fundamentada em um conceito amplo de violência, que, entre outros, abrange a repressão associada à destruição do inimigo político, com vistas a mostrar que, apesar de elucidar práticas de tortura e sequestro durante a ditadura militar argentina, o projeto estético desta narrativa fílmica faz dela um filme da inquietação, na medida em que opta pela não-exposição da violência.

Ivone dos Santos Veloso e Marli Tereza Furtado analisam "as figurações da infância e da criança" no romance Chove nos Campos de Cachoeira (1941), do escritor paraense Dalcídio Jurandir. Em seu livro de estréia Jurandir coloca em cena meninos e moleques marcados pela vida constrangida. De acordo com as autoras essas personagens encenam, dentro do universo infantil presente no romance, a luta de classes entre os desvalidos e os mais privilegiados socialmente.

O artigo "Fakt und Fiktion im historischen Film Das Leben der Anderen", de Johanna Henriette Lehmann, discute em que medida parâmetros historiográficos podem ser aplicados como critérios para instrumentalizar a análise de um filme histórico. Para dar conta da proposta a autora analisa o filme Das Leben der Anderen (A vida dos outros).

Em "Humanização das vítimas do conflito armado colombiano e Colorado (fotografia), Molano (literatura) e Salcedo (performance"), artigo de Juliana Leal, encontramos uma argumentação consistente sobre o processo de desterritorialização da população rural colombiana, fundamentalmente indígenas e afrocolombianos, sustentado pelo interesse de vários atores, entre eles, o Estado. Em contrapartida, a autora mostra como artistas colombianos, como Alfredo Molano, Doris Salcedo e Jesús Abad Colorado realizam um trabalho artístico com essas comunidades, capaz de revelar "a importância que a arte tem enquanto dispositivo discursivo de memória para fazer frente (enfrentar, contestar, problematizar, publicizar, denunciar...)".

Lizandro Carlos Calegari em "Trauma, memória e testemunho: notas sobre A vida e a luta de uma sobrevivente do holocausto, de Sabina Kustin" reúne três categorias: trauma, memória e testemunho para analisar o relato testemunhal de Sabina Kustin. A hipótese indica que a escrita pode ser um meio de revisão do passado traumático e uma possibilidade de alívio ou amenização da dor. 
Por sua vez, no artigo "Narrativa e resistência: conto brasileiro contemporâneo", Luana Porto analisa os contos "Boi”, de Marçal Aquino, e "O sorriso de brinquedo", de Carlos Gildemar Pontes, com o objetivo de argumentar que a resistência pode se manifestar apoiada em situações de caráter conflitivo, estruturados na forma e no tema, e não necessariamente vinculados a episódios históricos específicos, que poderiam gerar um teor testemunhal ou uma memória de fatos sociais representados nos contos.

Em "'ó vós que entrais perdei toda a esperança'. A estética da resistência no cinema argentino", artigo de Neiva Graziadei, encontramos a análise de cinco filmes produzidos durante a última ditadura cívico-militar na Argentina ocorrida entre os anos de 1970 e 1980. La historia oficial (1985) La noche de los lápices (1986), Garage Olimpo (1999), Kamchatka (2002) e Kóblic (2016). Graziadei parte da hipótese de que os filmes resultam de uma memória aberta e representam uma nítida e enfática atitude de oposição à ditadura como também às tentativas de apagamento da memória.

Raphael Cyrill Vásquez Leeder, autor do artigo ”Gewaltdarstellungen im Fernsehen. Eine Analyse der Serie Deutschland 83”, analisa a série alemã para TV Deutschland 83 (Alemanha 83), que trata das tensões entre a Alemanha Ocidental e a Alemanha Oriental. Leeder avalia que o conteúdo apresentado na série faz uso em diversos planos da representação da violência física e psíquica. A hipótese a movimentar o estudo é que as tensões humanas, desenvolvidas na série, representam simbolicamente a escalada da violência durante a Guerra Fria.

Em "A memória e a identidade em História de um pescador de Inglês de Sousa", Ronaldo Júnior Pantoja Rodrigues e Carlos Henrique Lopes de Almeida analisam o conto inglesiano identificado no título, observando como as formas de representação dos mecanismos de exploração da Amazônia se impõem como uma constante na produção literária deste escritor, na medida em que realiza um intenso exercício de recuperação da memória e de valorização da identidade da região em suas produções. Os autores apostam na hipótese de que Inglês de Sousa investe na representação de aspectos próprios da região, a partir de uma memória que não é sua, mas que vem a sua obra por necessidade de estabelecer vínculos afetivos e políticos com a região.

Em “A narrativa do perpetrador no Brasil: Memórias quase póstumas de um ex-torturador e Memórias de uma guerra suja", Tânia Sarmento-Pantoja mostra como a categoria "narrativa do perpetrador" pode manter vínculos com a categoria "romance do ditador" ou "narrativa do ditador", ao mesmo tempo em que as ultrapassa em autonomia, constituindo delimitação e complexidade próprias.

O texto que finaliza o presente dossiê aposta em uma relação original entre a experiência do confinamento e a literatura. Em "Nos moinhos do cárcere: Dalcídio Jurandir, leitor de Dom Quixote 
de la Mancha", Viviane Dantas Moraes traça uma reflexão sobre os papéis exercidos pelos autores em uma situação de exceção, a partir da ótica do escritor na sua experiência enquanto leitor no cárcere. De acordo com Dantas o contato com obras literárias, em especial a do Quixote, em um contexto de opressão pode ter impulsionado os projetos estéticos e éticos do escritor-leitor Dalcídio Jurandir, que foi por duas vezes prisioneiro durante o Estado Novo, por razões de estado.

Agradecemos a contribuição dos autores que disponibilizaram seus textos e desejamos uma excelente leitura e inspiração para novas reflexões e estudos aos nossos leitores.

As organizadoras 